\title{
The Correlation between Perception of Stigma of HIV/AIDS and Utilization of Voluntary Counseling and Testing and Care, Support and Treatment Polyclinic at Djoelham Hospital, Binjai
}

\author{
Ratih Sufra Rizkani' ${ }^{1}$, Surya Utama ${ }^{2}$, Erna Mutiara3) \\ ${ }^{1)}$ Master Program in Public Health Faculty, Universitas Sumatera Utara, Medan, Indonesia \\ 2)Department of Health administration and Policy in Public Health Faculty, \\ Universitas Sumatera Utara, Medan, Indonesia \\ 3)Department of Population and Biostatistics in Public Health Faculty, \\ Universitas Sumatera Utara, Medan, Indonesia
}

Background: The health care services for people living with HIV/AIDS (PLWH; hereinafter is referred to as PLWHA) at Polyclinic of Voluntary Counselling and Testing (hereinafter is referred to as VCT) and Care, Support and Treatment (hereinafter is referred to as CST) are not optimally utilized because of the large number of Follow-Up Loss by PLWHA. The utilization of the services in 2018 was only $47 \%$ of the determined target of $90 \%$. The objective of this study was to analyze the influence of individual characteristics such as age, sex, education level, marital status, and perception of HIV/AIDS negative stigma on the utilization of health services for HIV/AIDS at Polyclinic of VCT and CST.

Subjects and Method: This is a cross-sectional study. The population was all visitors at the Polyclinic who were diagnosed with HIV not later than March, 2018. Sixty eight patients were selected by using total sampling technique. The independent variables consisted of individual characteristics (age, sex, education level, marital status) and perception of HIV/AIDS negative stigma, whereas the dependent variables were the utilization of VCT and CST Polyclinic. The data were collected through questionnaires and were analyzed by multiple logistic regression method. Results: the perception of high negative stigma of HIV/AIDS has led PLWHA to underutilize the health services of VCT and CST Polyclinic (OR= $18.20 ; 95 \% \mathrm{CI}=3.89$ to $85.19 ; \mathrm{p}<0.001)$. The male PLWHA underutilized the health care services at VCT and CST Polyclinic $(\mathrm{OR}=4.91$; $95 \% \mathrm{CI}=1.19$ to $20.23 ; \mathrm{p}=0.028$ ).

Conclusion: the perception of high negative stigma of HIV/AIDS and being a male PLWHA allowed the underutilization of the health services at VCT and CST Polyclinic.

Keywords: perception of stigma, HIV, utilization

\section{Correspondence:}

Ratih Sufra Rizkani. A Student at Master Program of Public Health Faculty in University of Sumatera Utara, Medan. ratih86rizkani@gmail.com. Mobile: 085261776718

\section{Cite this as:}

Rizkani RS, Utama S, Mutiara E (2020). The Correlation between Perception of Stigma of HIV/AIDS and Utilization of Voluntary Counseling and Testing and Care, Support and Treatment Polyclinic at Djoelham Hospital, Binjai. J Health Promote Behav. 5(1): 26-34. https://doi.org/10.26911/thejhpb.2020.05.01.04 Journal of Health Promotion and Behavior is licensed under a Creative Commons Attribution-NonCommercial-ShareAlike 4.o International License.

\section{BACKGROUND}

HIV is the disease caused by Human Immunodeficiency Virus and destriys immune system. AIDS is the condition of body which shows some clinical symptoms and signs because of opportunistic infection resulted from the declines in immune system (Ditjen Bina Gizi and KIA, 2014). HIV is an infectious disease, and its infection may be passed through three ways. Nasronudin (2014), explains that HIV infection or transmission into body is passed through several ways: (1) Trans- 
mission from mothers to their babies (during their pregnancy, delivery, breastfeeding) which is often called vertical way, (2) Transsexual (i.e. heterosexual or homosexual relationship), (3) Contact between blood and blood product contaminated with HIV virus, which is called horizontal way.

HIV/AIDS was firstly found in Indonesia in 1987 and its dissemination until June, 2018 was 433 (84.2\%) in 514 cities throughout all provinces in Indonesia. The number of HIV patients in Indonesia until June, 2018 was 301,959 people or $47 \%$ of estimation of PLWHA for 2018 i.e. 640,443 people. Until December, 2017, around 948 people died from AIDS. There are around 15,812 HIV patients and 3,916 AIDS patients in Sumatera Utara Province. Sumatera Utara Province ranks $7^{\text {th }}$ out of $10^{\text {th }}$ in the number of HIV patients in the provinces throughout Indonesia (Ditjen P2P, 2018).

The clients or patients who have taken HIV tests, if the test results are positive, need necessary treatment, support, and medication (referred to as PDP) (MoH RI, 2014). WHO (2017) explained that there were 3,771 HIV test services operating in 2016 and that there was still a large gap among number of health care services, number of population requiring tests, and number of tests to be performed. In addition, nearly half of those who have ever had ART lost to follow up their medication, died, and lost contact.

Utilization of HIV/AIDS health care services is compulsory people who have been diagnosed with HIV positive, particularly the utilization of ARV health care services. PLWHA must avoid viral resistance to ARV drugs and therapy failures; the adherence to ARV medication in PLWHA has become high > 95\% (Ditjen P2PL, 2012), so that they are obliged to regularly utilize HIV/AIDS Polyclinic for ARV medication.

According to the preliminary survey, it was discovered in 2018 that merely 103 people out of 220 people detected with HIV (+) in VCT and CST Polyclinic utilized HIV/AIDS the health care services. By the end of 2018, only $47 \%$ of PLWHA out of the targeted 90\% utilized the VCT and CST Polyclinic at the Regional General Hospital in Binjai.

\section{SUBJECTS AND METHOD}

\section{Study Design}

This study is survey research with crosssectional design, which was conducted in April, 2019 at dr. Djoelham Hospital, one of the hospitals assigned as the referral hospitals for PLWHA pursuant to the Decree of Minister of Health No.451/MENKES/SK/XII year 2012.

\section{Population and Sample}

The selected samples were those who met some criteria, namely (1) Having been diagnosed as PLWHA in the laboratory test results not later than March, 2018; (2) visited the VCT and CST Polyclinic at the hospital to utilize the available health care services during the study period, April, 2019; and (3) were at least $>17$ years old or 18 years old during study. Total sampling technique was employed. The samples consisted of 68 people.

\section{Study Variables}

The dependent variable was utilization of VCT and CST Polyclinic, whereas the independent variables were age, sex, level education, marital status, and perception of respondents who were PLWHA of the negative stigma of HIV/AIDS.

4. Operational Definition of Variables Utilization is the frequency of visitation; how many times PLWHA visit the Polyclinic within last year. The respondents were assessed to have underutilized the Polyclinic if they visited the Polyclinic for 1 to 9 times in a year, and to have properly utilized the Polyclinic if they visited it 10 to 12 times in a year. Age is the unit of time used to measure the existence of the respondents ever since their 
birth until the time this research was conducted, with sample criterion $>17$ years old.

Sex is the difference in biological forms, characteristics, and functions of males and females which determine their roles to continue their lines of descent.

Education is the highest level of formal learning ever taken by respondents to obtain a letter of completion (diploma).

Marital status is an institution in the culture, religion, and local regulations that formalize interpersonal relations, in this case it is divided into 2 groups; namely (a) not married yet and never married (single), and (b) married.

The perception of HIV/AIDS stigma is the act of collecting, recognizing, and interpreting the views of people who judge themselves negatively, namely feeling of shame and fear

\section{Study Instruments}

The data were collected through questionnaires which had previously been tested for validity and reliability

\section{Data Analysis}

The data analysis method employed in this study was the multiple logistic regression method, which analyzed the effect of age, sex, education level, marital status, and perception of HIV/AIDS stigma on the utilization of HIV/AIDS health care services in VCT and CST Polyclinic at Dr. RM Djoelham Hospital.

\section{Research Ethic}

The study was conducted by complying with the prevailing rules and procedures, in addition to obtaining direct consent from the respondents, maintaining the confidentiality of patients' identity, the study had also been approved by the hospital (Dr. Djoelham Hospital, Binjai) through the letter number: 0716705 .

\section{RESULTS}

\section{A. Sample Characteristics}

The results discovered the characteristics of PLWHA respondents as illustrated in the following Table 1.

Table 1. Sample characteristics

\begin{tabular}{lcc}
\hline \multicolumn{1}{c}{ Category } & Frequency (n) & Percentage (\%) \\
\hline Age & 48 & $70.6 \%$ \\
$18-40$ years old & 20 & $29.4 \%$ \\
$\begin{array}{l}41-65 \text { years old } \\
\text { Sex }\end{array}$ & 46 & 67.6 \\
Male & 22 & 32.4 \\
Female & & \\
Education & 18 & $26.5 \%$ \\
$\begin{array}{l}\text { Poorly educated } \\
\text { (Elementary School - Junior High School) }\end{array}$ & & \\
Well-educated & 50 & $73.5 \%$ \\
(Senior High School - University) & & \\
Marital Status & 41 & $60.3 \%$ \\
Not ye or Never married (single) & 27 & $39.7 \%$ \\
Married & & $45.6 \%$ \\
Negative stigma of HIV/AIDS & 31 & $54.4 \%$ \\
Highly perceived stigma & 37 & \\
\hline
\end{tabular}

Table 1 illustrates the results of the univariate analysis and the characteristics of the individuals who were PLWHA respondents. The study results demonstrated that among 68 respondents, their ages were dominantly classified into early adult category represent- 
ted by 48 people or $70.6 \%$, male respondents were the ones who made the most utilization of health care services i.e. 46 male PLWHA or $67.6 \%$, most of them were well-educated i.e. 50 people or $73.5 \%$, and they were mostly single (namely the PLWHA who were not yet married or had been married but got divorced) i.e. 41 people or $60.3 \%$

These results indicated that among 68 PLWHA, the youngest respondent was 19 years old, and the oldest was 63 years old, they were dominated by early adult age category (18-40 years old) i.e. 48 people or $70.6 \%$, while the others were in middle-late adulthood age category ( $41-65$ years old) i.e. 20 people or $19.4 \%$. This study also found that the respondents who mostly suffered from HIV/AIDS and utilized the health care services of HIV/AIDS were at their productive ages.
It was also discovered that regarding the respondents' education level; they were dominated by well-educated people, and their marital status was mostly single or without spouses. That the respondents had high level of education allowed them to recognize the symptoms of a disease, and they were willing to search for health care services. Moreover, the results of the study also found out that the respondents who made the most utilization of health care services were single (not yet or never married).

\section{B. Bivariate Analysis}

The bivariate analysis was conducted by applying chi-square test as presented in Table 2.

Table 2. The Correlations of respondents' characteristics and perception of negative stigma of HIV/AIDS with the utilization of VCT and CST Polyclinic at Dr. Djoelham Hospital in Binjai.

\begin{tabular}{|c|c|c|c|c|c|c|}
\hline \multirow{3}{*}{ Variable } & \multicolumn{4}{|c|}{ Utilization of health care services } & \multirow{3}{*}{$\mathbf{O R}$} & \multirow{3}{*}{$\mathbf{p}$} \\
\hline & \multicolumn{2}{|c|}{ underutilize } & \multicolumn{2}{|c|}{ well utilize } & & \\
\hline & $\mathbf{N}$ & $\%$ & $\mathbf{N}$ & $\%$ & & \\
\hline \multicolumn{7}{|l|}{ Age } \\
\hline Middle aged-late & 14 & 70.0 & 6 & 30.0 & \multirow{4}{*}{1.40} & \multirow{4}{*}{0.555} \\
\hline (41-65) y.o. & & & & & & \\
\hline Early adult (18-40) y.o. & 30 & 62.5 & 18 & $37 \cdot 5$ & & \\
\hline Sex & & & & & & \\
\hline Male & 33 & 71.7 & 13 & 28.3 & \multirow{2}{*}{2.54} & \multirow{2}{*}{0.079} \\
\hline Females & 11 & 50.0 & 11 & 50.0 & & \\
\hline \multicolumn{7}{|l|}{ Education Level } \\
\hline Poorly Educated & 14 & 77.8 & 4 & 22.2 & \multirow{3}{*}{2.33} & \multirow[b]{2}{*}{0.165} \\
\hline Well Educated & 30 & 60.0 & 20 & 40.0 & & \\
\hline \multicolumn{6}{|l|}{ Marital Status } & \\
\hline Not yet or never married & 27 & 65.9 & 14 & 34.1 & \multirow{3}{*}{1.13} & \multirow[b]{2}{*}{0.807} \\
\hline Married & 17 & 63.0 & 10 & 37.0 & & \\
\hline \multicolumn{6}{|c|}{ Negative stigma of HIV/AIDS } & \\
\hline Highly perceived stigma & 28 & 90.3 & 3 & 9.7 & & \\
\hline Low perceived stigma & 16 & 70.7 & 21 & 56.8 & 12.25 & $<0.001$ \\
\hline
\end{tabular}


The results of the bivariate analysis showed that 14 patients (70.0\%) who underutilized the health care services were 41-65 years old, 18 patients (37.5\%) who well utilized the health care services were 18-40 yaers old. The results of chi-square test indicated that the patients in their early adulthood (1840 years old) had 1.40 times more likelihood to utilize the health care services for HIV/AIDS at VCT and CST Polyclinic compared to those in their middle-late adulthood (41-65 years old), but it was statistically insignificant $(p=0.555)$. The results of the bivariate analysis also demonstrated that 27 patients (65.9\%) who underutilized the health care services were not yet or never married (single), and 10 patients (37.0\%) who well utilized the health care services were married HIV patients. The results of chi-square test indicated that married PLWHA had 1.13 times more likelihood to utilize the health care services for HIV/AIDS in VCT and CST Polyclinic compared to single PLWHA either those who were not yet or never married; however, it is statistically insignificant $(\mathrm{p}=$ o.807). Based on the result of the bivariate analysis, it was discovered that age and marital status were not correlated with the utilization of HIV/AIDS health care services in VCT and CST Polyclinic because it showed value of $\mathrm{p}>0.05$. Moreover, age and marital status also obtained value of $p>0.25$; thus, it was not a candidate in the multivariate analysis that would be conducted.

The succeeding step of this study was multivariate analysis of 3 variables with value of $\mathrm{p}<0.25$ namely sex, education level, and perception of HIV/AIDS stigma.

\section{Multivariate analysis}

The results of the multivariate analysis are presented in Table 3.

Table 3. The results of multiple logistic regression analysis

\begin{tabular}{|c|c|c|c|c|}
\hline \multirow{2}{*}{ Independent Variables } & \multirow{2}{*}{$\mathbf{O R}$} & \multicolumn{2}{|c|}{$95 \% \mathrm{CI}$} & \multirow[b]{2}{*}{$\mathbf{p}$} \\
\hline & & Lower limit & Upper limit & \\
\hline Male & 4.91 & 1.19 & 20.23 & 0.028 \\
\hline Perception of high negative-stigma & 18.20 & 3.89 & 85.19 & $<0.001$ \\
\hline $\begin{array}{l}\mathrm{N} \text { observation }=68 \\
-2 \text { log likelihood }=64.71 \\
\text { Nagelkerke } \mathrm{R}^{2}=40.3 \%\end{array}$ & & & & \\
\hline
\end{tabular}

The results of the multivariate analysis demonstrated that two variables had effects on utilization of the healths care services for HIV/AIDS, namely sex (OR= 4.91; 95\% CI= 1.19 to $20.23 ; \mathrm{p}=0.028$ ), and perceptino of negative stigma of $\mathrm{HIV} / \mathrm{AIDS}(\mathrm{OR}=18.20$; $95 \% \mathrm{CI}=3.89$ to $85.19 ; \mathrm{p}<0.001)$.

The value of OR in male patients was 4.91, indicating that the likelihood of male patients to underutilize the HIV/AIDS health care services was 4.91 less than that of the female patients; meaning that the female patients utilized better the HIV/AIDS health care services.

The value of OR for perception og negative stigma of HIV/AIDS was high i.e. 18.20. It indicated that the PLWHA who perceived high negative stigma of HIV/AIDS had 18.20 times higher likelihood to underutilize the health care services compared to those who perceived low negative stigma.

The results of the multivariate analysis showed that the value of nagelkerke was $40.3 \%$, in this study, the effect of sex and perception of negative stigma of HIV/AIDS 
on utilization of VCT and CST Polyclinic was 40.3\%, and the other $59.7 \%$ was explained by the other factors apart from the independent variables in the equation resulted from the logistic regression test. The final results of the multivariate analysis found that the perception of negative stigma of HIV/AIDS was the variable with the most dominant effects on PLWHA to utilize VCT and CST Polyclinic.

\section{DISCUSSION}

The results of the multivariate analysis indicated that the highly perceived negative stigma of HIV/AIDS influenced PLWHA to underutilize VCT and CST Polyclinic. Effendi (2016) explained that perception if the results of one's interpretation to any stimulus or incident received based on the information and their experience to the stimulus. Sangadji and Sopiah (2013) explained similar information may be interpreted differently by differrent individuals. Individuals' perception of something depends on their knowledge, experience, education, interest, attention, and so on.

In addition to being lethal, HIV/AIDS also leads to many psychological issues such as desperation, distress, and negative thoughts as well as discrimination from other people that cause psychological stress (Green and Setyowati, 2004). Ministry of Health (2012), defines stigma as a social label of prejudice such as bad image and views in order to separate and discredit an individual from other people or a group of people.

When one is diagnosed with HIV-positive, he has to encounter society's stigma to him. HIV/AIDS-infected people who experience 3 stressors, namely biological stressor due to HIV, psychological stressor for being diagnosed with HIV/AIDS infection, and psychosocial stressor due to the stigma and discrimination from family and society (Nasronudin, 2014).
The study conducted by Ardani and Handayani, (2017) explained that stigma is the significant hindrance to PLWHA to prevent and cure HIV. Any form of stigma from the society or self-stigma lead individuals to label themselves "being rejected" in searching for medication. Another study conducted by Aminuddin (2017), demonstrated that the percentage of PLWHA who do not utilize VCT services was higher in the group who states that there is a comparison between the groups which state that stigma exists and stigma does not exist.

Based on the theory of utilization proposed by Dever (1984), it is discovered that the psychosocial factors from consumers (utilizers of health care service) that influence the utilization is, one among others, perception of a disease. HIV/AIDS is not separated from its negative stigma. Shaluhiyah et al. (2015) explained that the form of stigma from the society to PLWHA is like the unavailability of food for PLWHA, not allowing children to play with the children of PLWHA, not willing to share toilets, even not willing to live nearby people with symptoms of HIV/AIDS. When there is an HIV/AIDS patient in the family, they fear to sleep together with the person, and refuse to treat such as preparing food and cleaning dining set.

This study that was conducted at VCT and CST Polyclinic at dr. Djoelham Hospital in Binjai presented that among 68 PLWA : (1) PLWHA always felt ashamed with their disease, represented by 25 people or $36.8 \%$, (2) they felt that other people were afraid to have physical contact with them, represented by 22 people or $32.4 \%$, (3) the always want to alienate themselves, represented by 13 people or $38.2 \%$, (4) they fear that many people would be aware of their disease if they had medication, represented by 26 people or $38.2 \%$, (5) they also felt ashamed every time they visited the Polyclinic and were worried 
that other people would recognize them, represented by 30 people or $44.1 \%$.

Moreover, the results from interviews with the PLWHA respondents demonstrated that PLWHA still had perception of HIV/AIDS such as: (1) they considered HIV/AIDS dangerous, (2) they thought HIV/AIDS as a nasty disease for the society (3) they felt that HIV/AIDS embarrassed them and their families. Negative perceptions towards PLWHA are some of the common manifestations of AIDS stigma which leads to discrimination and prejudice attitudes (Valdiserri, 2012; Holzemer et al., 2009; Mokoae et al., 2008; Stangl, 2013.

Based on the above explanation, it is necessary to make effort to reduce the perception of negative stigma of HIV/AIDS. One of the efforts that can be made is counseling to PLWHA. Quality counselor will support successful counseling. Carl Rogers (1971) in Lesmana (2005), explained that in order to produce effective counseling, agar counselors should have some characteristics such as congruence, acceptance, and empathy. Empathy is the ability of counselor to feel the clients. In order to encourage PLWHA to have adaptive behavior, they need to have counseling with behavioral approach, in which a counselor functions as a consultant, teacher, advisor, supporter, and facilitator.

In addition to counseling, PLWHA may need to be involved in Supporting Group from People at same age (referred to as KDS) as an effort to reduce perception of negative stigma, and to rebuild the confidence of PLWHA. Support from people at same age is the support that is received from or given by people have ever suffered or are suffering from HIV/AIDS. KDS is one of non-medical therapies, and is effective to help PLWHA emotionally and practically (Murni et al., 2013).

Moreover, it was discovered that sex had effects on the utilization of VCT and CST
Polyclinic. In the theory of utilization proposed by Andersen and Newman (1973), the demographic factors such as age and are predisposition that can influence people to utilize health care services. Female PLWHA are known to utilize better the provided health care services. The results of this study discovered that male PLWHA had 4.9 times higher likelihood to underutilize the health care services compared to the female PLWHA.

Gender inequalities affect men and women's experience of AIDS-related illness differently. They also affect the provision of care and support within households as regards who provides care, which activities are undertaken, and how caregivers are supported (WHO, 2009).

This result is not contrary with another study results conducted by Wulandari (2015), which state that the patients who had routine ARV medication were mostly female, single, had middle scale income, and worked as entrepreneurs. Since sex had effects on utilization, male PLWHA are required to have strong motivation so that they can regularly utilize health service, either motivation from family, health personnel, or KDS.

\section{AUTHOR CONTRIBUTION}

Ratih Sufra Rizkani and Surya Utama conceived the presented idea. Ratih Sufra Rizkani developed the theory and performed the computation. Surya Utama and Erna Mutiara verified the analytical methods and encouraged Ratih Sufra Rizkani to investigate (a specific aspect) and supervised the findings of this study. All authors discussed the results and contributed to the final manuscript.

\section{CONFLICT OF INTEREST}

There is no conflict of interest in this study. The study was conducted in the absence of any commercial or financial relationships. 
Rizkani et al./ The Correlation between Perception of Stigma of HIV/AIDS

\section{FUNDING AND SPONSORSHIP}

This study was done using authors funds.

\section{ACKNOWLEDGEMENT}

Acknowledgments were conveyed by authors to the Dr. Djoelham Hospital for allowing this study to be conducted.

\section{REFERENCE}

Andersen R, Newman J (1973). Societal and individual determinant of medical care utilization in the united stated. The Milbank Memorial Fund Quarterly: Health and Society, 51(1): 95124.

Aminuddin A (2017). Hubungan stigma terhadap ODHA dengan minat melakukan VCT pada ibu rumah tangga di RW 14 Sosmenduran Gedongtengen Yogyakarta. Skripsi. Yogyakarta: Fakultas Ilmu Kesehatan Universitas Aisyiyah Yogyakarta.

Ardani I, Handayani S (2017). Stigma terhadap orang dengan HIV/AIDS (ODHA) sebagai hambatan pencarian pengobatan: Studi Kasus pada Pecandu Narkoba Suntik di Jakarta. Buletin Penelitian Kesehatan 45 (2): 81-88.

Dever GEA (1984). Epidemiology in health services management. Marylan: Aspen Systems Corporation.

Ditjen Bina Gizi and KIA (2014). Pedoman pelaksanan pencegahan penularan HIV dan sifilis dari ibu ke anak bagi tenaga kesehatan. Jakarta: Kementerian Kesehatan RI.

Ditjen P2PL (2012). Pedoman penerapan layanan komprehensif HIV/IMS berkesinambungan. Jakarta: Kementerian Kesehatan RI.

Ditjen P2P (2018). Laporan perkembangan HIV/AIDS \& penyakit infeksi menular seksual (PIMS) triwulan I tahun 2018. Jakarta: Kementerian Kesehatan RI.
Effendi U (2016). Psikologi konsumen. Jakarta: Rajawali Press.

Green CW, Setyowati H (2004). Terapi alternatif. Jakarta: Yayasan Spiritia.

Holzemer WL, Human S, Arudo J, Rosa ME, Hamilton MJ, Corless I, et al. (2009). Exploring HIV stigma and quality of life for persons living with HIV infection. J Assoc Nurses AIDS Care. 2009; 20(3): 161-168. doi: 10.1016/j.jana.2009.02.002

Lesmana JM (2005). Dasar-dasar konseling. Fakultas Psikologi UI: UI Press.

Ministry of Health (2012). Buku pedoman penghapusan stigma dan diskriminasi bagi pengelola program, petugas layanan kesehatan dan kader. Jakarta: Bakti Husada

Mokoae LN, Greeff M, Phethu RD, Uys LR, Naidoo JR, Kohi TW, et al. (2008). Coping with HIV/AIDS stigma in five African countries. J Assoc Nurses AIDS Care. 19(2): 137-146. doi: 10.1016/j.jana.2007.11.004

Murni S, Green CW, Djauzi, Setiyanto A, Okta S (2013). Hidup dengan HIV seri buku kecil. Jakarta: Yayasan Spiritia.

Nasronudin (2014). HIV \& AIDS pendekatan biologi molekuler, klinis dan sosial edisi 2. Surabaya: Airlangga University Press.

Permenkes RI No.74 Tahun 2014. Pedoman pelaksanaan konseling dan tes HIV. Jakarta.

Sangadji EM, Sopiah (2013). Perilaku konsumen pendekatan praktis disertai himpunan jurnal penelitian. Yogyakarta: ANDI.

Shaluhiyah Z, Musthofa SB, Widjanarko B (2015). Stigma masyarakat terhadap orang dengan HIV/AIDS. Jurnal Kesehatan Masyarakat Nasional 9(4): 333-339.

Stangl AL, Grossman CI (2013). Global action to reduce HIV stigma and 
Rizkani et al./ The Correlation between Perception of Stigma of HIV/AIDS

discrimination. J Int AIDS Soc.16: 2. doi: 10.7448/IAS.16.3.18934

Valdiserri RO (2012). HIV/AIDS stigma: an impediment to public health. Am J Public Health. 92(3): 341-342.

WHO (2009). Home-based care for people living with HIV. Geneva: World Health Organization.
WHO (2017). Kajian nasional respon HIV di bidang kesehatan republik Indonesia laporan 2017. Jakarta: Kementerian Kesehatan RI.

Wulandari Y (2015). Hubungan karakteristik pasien dengan tingkat kepatuhan terapi ARV di rawat jalan UPIPI rumah sakit Dr. Soetomo. Jurnal KESMAS 9(1): 1-6. 